\title{
PENGARUH PERSEPSI HARGA DAN CITRA MEREK TERHADAP KEPUASAN PELANGGAN PENGGUNA JASA TRANSPORTASI OJEK ONLINE (STUDI KASUS PELANGGAN GRAB DI KOTA PALEMBANG)
}

\author{
( Abdullah Rasjid, Agung Laksono ) \\ Dosen Tetap Fakultas Ekonomi Universitas Palembang
}

\begin{abstract}
ABSTRAK
Penelitian ini bertujuan untuk menguji pengaruh tingkat persepsi harga dan citra merek terhadap kepuasan pelanggan jasa transportasi ojek online Grab di kota palembang. Kepuasan pelanggan merupakan ukuran perusahaan dalam memperbaiki atau meningkatkan kualitas suatu usaha. Populasi dalam penelitian ini adalah pelanggan jasa transportasi ojek online (Grab) di kota palembang yang sebanyak 500 orang. Teknik pengambilan sampel dalam penelitian ini menggunakan teknik Accidental Sampling. Jenis datanya adalah data primer dan data skunder. Metode pengumpulan data menggunakan kuesioner. Teknik analisis yang digunakan adalah regresi berganda.

Hasil analisis menggunakan program SPSS versi 23 menunjukkan bahwa persepsi harga dan citra merek berpengaruh positif dan signifikan terhadap kepuasan pelanggan dari hasil koefisiensi regressi yang didapat.
\end{abstract}

Kata Kunci : Persepsi Harga, Citra Merek, dan Kepuasan Pelanggan

\section{ABSTRACT}

The research aims to test the impact of price perception levels and brand image on customer satisfaction of an online taxi service grab in the city of palembang. Customer satisfaction is a company measure of improving or improving the quality of a business.

The population in this study is a customer of an online taxi service (grab) at the palembang city of 500 people. The sample sampling technique in this study is sampling techniques. The type of data is the primary and secondary data. Data collection methods use questionnaires. The analysis technique used was regression.

Analysis results using version 23 SPSS program shows that price perceptions and brand images have a positive and significant impact on customer satisfaction from the obtained regression coefficients.

Key Words : price perception levels, brand image and customer satisfaction

\subsection{Latar Belakang Masalah}

Pada saat ini globalisasi nampaknya bukan hanya sekedar kata tanpa makna saja, globalisasi mulai menjangkit seluruh aspek dalam kehidupan manusia. Bahkan Masyarakat kota kecil pun mulai menunjukkan eksistensinya dengan ikut masuk kedalam arus globalisasi, hampir semua aspek yang ditelan arus globalisasi ini mulai berbenah diri, kemudahan dalam teknologi informasi adalah cikal bakal dari perubahan ini. Layaknya arus mobilitas kota 
yang tinggi membuat seluruh penduduknya sering terjebak dalam situasi kemacetan, dari hal inilah muncul anak anak muda yang mengambil ini sebagai peluang bisnis, dengan berbekal teknologi maka para pebisnis ini membuat sebuah aplikasi yang mampu mengakomodasi segala keluhan baik dari sisi kemacetan dan juga lapangan pekerjaan.

Seiring dengan kemajuan pesat ini beberapa penguasa jasa transportasi online mulai mencari perhatian konsumen agar mereka dapat bersaing dan terus berkembang, tantangan inilah yang menjadi awal PT Grab Indonesia mulai melakukan beberapa upaya dalam memuaskan konsumennya. Perusahaan yang lahir pada tahun 2012 di Malaysia ini awalnya bernama GrabTaxi dengan modal 25 ribu dollar AS, namun kisah itu tidak semudah yang kita bayangkan awal mula didirikan GrabTaxi mendapatkan banyak penolakan dari perusahaan taksi untuk bekerja sama. Hingga akhirnya usaha ini mulai mendapatkan apresiasi yang baik dari mitranya dikarenakan mulai majunya.Di Indonesia sendiri Grab masuk pada tahun 2014 dan mulai membuka beberapa layanan seperti GrabCar, Grabbike, Grabfood, dan Grabekspres. Dari beberapa layanan tersebut tentu Grab memiliki kompetitor besar sekelas Gojek, dengan inilah mereka berlomba lomba mencari kepuasan pelanggan agar menjadi super aplikasi terbaik. Tentu aspek kemudahan, kecepatan, kepastian harga, dan keamanan menjadi tolak ukur dari kepuasan pelanggan. Dulunya orang mesti menunggu ojek ataupun taksi di pinggir jalan kini mereka hanya perlu menggoyangkan tangan di handphone lalu dalam beberapa menit grab akan mengirimkan mitranya ke lokasi pemesanan konsumen tersebut. Semakin banyaknya jumlah konsumen membuat tumbuh beberapa aplikator baru yang ikut meramaikan persaingan.Faktor yang menjadi penyebab terjadinya hal tersebut yakni persaingan dari harga dan banyaknya alternatif pilihan jasa ojek online, hal ini membuat konsumen menjadi sangat selektif. Konsumen akan memilih salah satu aplikasi yang mereka anggap dapat sesuai dengan kebutuhan dan keinginan mereka. Mengantisipasi hal itu maka Grab harus bisa menciptakan kepuasan konsumen.

Kepuasan konsumen merupakan faktor yang sangat penting bagi keberadaan, kelangsungan, dan perkembangan perusahaan. Saat ini banyak perusahaan memahami arti penting dari kepuasan konsumen serta telah menjalankan beberapa strategi guna memberikan layanan yang prima. Menurut Bachtiar (2011), kepuasan konsumen merupakan perasaan positif konsumen yang berhubungan dengan produk / jasa selama menggunakan atau setelah menggunakan jasa atau produk.

Pada hakikatnya tujuan bisnis adalah untuk menciptakan dan mempertahankan para konsumen.Konsumen dalam pandangan tradisional adalah orang yang membeli dan menggunakan produknya.Semua usaha manajemen diarahkan pada satu tujuan utama, yaitu terciptanya kepuasan konsumen. Harapan konsumen memegang perananan penting dan sangat besar pengaruhnya dalam menentukan kualitas produk (barang dan jasa) dan mengevaluasinya konsumen akan menggunakan harapannya sebagai standar atau acuan. Karena konsumen adalah orang yang menerima hasil pekerjaan seseorang atau suatu organisasi, maka hanya mereka yang dapat menentukan kualitasnya seperti apa dan hanya mereka yang dapat menyampaikan apa dan bagaimana kebutuhan mereka. Konsumen yang puas akan setia lebih lama, kurang sensitif terhadap harga dan memberi komentar yang baik tentang perusahaan. Menurut Lovelock dan Wirtz yang dikutip oleh Fandy Tjiptono (2016), kepuasan adalah suatu sikap yang 
diputuskan berdasarkan pengalaman yang didapatkan.Sangat dibutuhkan penelitian untuk membuktikan ada atau tidaknya harapan sebelumnya yang merupakan bagian terpenting dalam kepuasan.

Harga jual pada hakekatnya merupakan tawaran kepada para konsumen. Apabila konsumen menerima harga tersebut pada saat akan melakukan pembelian, maka produk tersebut akan laku, sebaliknya bila konsumen menolaknya pada saat akan melakukan pembelian, maka diperlukan peninjauan kembali harga jualnya. Ada kemungkinan bahwa konsumen memiliki ketidaksesuaian setelah melakukan pembelian karena mungkin harganya dianggap terlalu mahal atau karena tidak sesuai dengan keinginan dan gambaran sebelumnya, Dengan demikian diperlukan strategi penetapan harga yang tepat.

Strategi penetapan harga sangat penting untuk menarik perhatian konsumen. Harga yang tepat adalah harga yang sesuai dengan kualitas produk suatu barang dan harga tersebut dapat memberikan kepuasan kepada konsumen. Para pemasar berusaha untuk mencapai sasaran tertentu melalui komponen-komponen penetapan harga.Beberapa perusahaan mencoba untuk meningkatkan keuntungan dengan menetapkan harga rendah untuk menarik bisnis baru.

Selain itu, apabila dicermati ada banyak hal yang harus dibenahi dalam layanan Grabbike yang ada saat ini khususnya masalah keselamatan dan harga layanan.Terkait keselamatan ternyata di lapangan pengemudi banyak sekali yang tidak menghiraukan rambu-rambu lalu lintas sehingga sangat membahayakan konsumen. Ini sangatlah berpengaruh dalam membentuk citra grab sebagai layanan transportasi yang berbasis online yang aman. Maka dari itu perusahaan sangatlah ketat dalam melakukan penindakan driver/mitranya yang tidak sesuai dengan standarisasi keselamatan yang ditetapkan oleh grab.

Tarif yang diatur pemerintah dalam peraturan Menteri perhubungan:

Tabel 1.1

\section{Aturan Tarif Di Indonesia}

\begin{tabular}{|l|l|l|l|}
\hline \multicolumn{1}{|c|}{ Biaya Jasa } & \multicolumn{1}{|c|}{ Zona 1 } & \multicolumn{1}{c|}{ Zona 2 } & \multicolumn{1}{c|}{ Zona 3 } \\
\hline Batas Bawah & Rp. 1.850 & Rp. 2.000 & Rp. 2.100 \\
\hline Batas Atas & Rp. 2.300 & Rp. 2.500 & Rp. 2.600 \\
\hline Batas Jasa Minimal & Rp 7.000- Rp & Rp 8.000- Rp & Rp 8.000- Rp \\
0-4km & 10.000 & 10.000 & 10.000 \\
\hline
\end{tabular}

(Juliati,Sri Dalam Tribun News edisi 1 September 2019).

Batas jasa minimal adalah biaya jasa yang dibayarkan oleh pelanggan dengan jarak rendah yaitu 0-4 km, Batas bawah adalah tarif yang diberlakukan sebagai tarif minimal perkilometer, batas atas ini adalah tarif yang diberlakukan kepada konsumen sebagai acuan tarif tertinggi yang berlaku perkilometer. Zona 1 terdiri dari Sumatera, Bali, Jawa tanpa Jabodetabek , Zona 2 terdiri dari Jakarta, Bogor, Depok, Tanggerang dan
Bekasi , Zona 3 Kalimantan, Sulawesi, Maluku, NTT.

Akan tetapi di kondisi di lapangan ternyata aturan ini tidak serta merta diikuti oleh semua aplikator, ada beberapa yang masih menggunakan tarif di batas bawah atau tidak sesuai dari aturan tersebut misalnya Maxim perusahaan aplikator jasa transportasi online asal Rusia ini masih memasang tarif dengan minimal Rp.5.000 , 
dari hasil survey yang saya lakukan ditemukan fakta menarik tentang permasalah harga ini . Survey dilakukan pada tanggal 28 febuari 2021 dengan melihat langsung harga yang tertera di aplikasi 3 aplikator besar yang menguasai pasar Indonesia dari layanan ojek online, survey ini dibuat dengan cara memesan ojek online dari 3 aplikasi dengan format tujuan yang sama yaitu dari jalan pipa reja menuju OPI Mall Palembang yang telah diukur melalui google maps dan mendapati jarak sejauh 14 $\mathrm{km}$.

Tabel 1.2

Perbandingan Harga 3 Aplikator Di Indonesia

\begin{tabular}{|l|l|l|}
\hline \multicolumn{1}{|c|}{ Transportasi Online } & \multicolumn{1}{|c|}{ Jarak Tempuh } & \multicolumn{1}{c|}{ Biaya Layanan } \\
\hline Grab & $14 \mathrm{Km}$ & Rp. 32.000 \\
\hline Gojek & $14 \mathrm{Km}$ & Rp. 34.000 \\
\hline Maxim & $14 \mathrm{Km}$ & Rp. 26.900 \\
\hline
\end{tabular}

Sumber : Aplikasi Grab, Gojek, Dan Maxim.

Bedasarkan dari tabel diatas dapat kita lihat bahwa dengan jarak tempuh yang sama 3 aplikator ini membuat 3 harga yang berbeda, ini sangat berdampak menurunkan citra merek pada grab yang kita tahu selalu dapat diandalkan dari sisi harga, Kepuasan pelanggan pun akan dipertaruhkan disini. Masalah ini menjadi sorotan banyak orang hingga membuat citra murah yang ada pada grab mulai berpindah pada maxim.

Berdasarkan paparan diatas, maka penulis berkeinginan untuk mengajukan sebuah penelitian yang berjudul “ PENGARUH PERSEPSI HARGA DAN CITRA MEREK TERHADAP KEPUASAN PELANGGAN JASA TRANSPORTASI ONLINE (STUDI KASUS PADA PELANGGAN GRAB DI KOTA PALEMBANG)".

\subsection{Tujuan Penelitian}

Tujuan dalam penelitian ini adalah

1. Untuk menilai bagaimana pengaruh persepsi harga terhadap kepuasan pelanggan.

2. Untuk menilai bagaimana pengaruh citra merek terhadap kepuasan pelanggan.

3. Untuk menilai bagaimana pengaruh persepsi harga dan citra merek terhadap kepuasan pelanggan.

\section{II . TINJAUAN PUSTAKA}

2.1 Kerangka Teori

2.1.1 Definisi Persepsi harga

Persepsi merupakan suatu proses pengorganisasian, penginterpretasian terhadap stimulus yang diterima oleh organisme atau individu sehingga menjadi sesuatu yang berarti, dan merupakan aktivitas yang integrated dalam diri individu. Respon sebagai akibat dari persepsi dapat diambil oleh individu dengan berbagai macam bentuk. Stimulus mana yang akan mendapatkan respon dari individu tergantung pada perhatian individu yang bersangkutan. Berdasarkan hal tersebut, perasaan, kemampuan berfikir, pengalamanpengalaman yang dimiliki individu tidak sama, maka dalam mempersepsi sesuatu stimulus, hasil persepsi mungkin akan berbeda antar individu satu dengan individu lain.

Syarat Terjadinya Persepsi Menurut Sunaryo (2013) syarat-syarat terjadinya persepsi adalah sebagai berikut:

1. Adanya objek yang dipersepsi

2. Adanya perhatian yang merupakan langkah pertama sebagai suatu persiapan dalam mengadakan persepsi . 
3. Adanya alat indera/reseptor yaitu alat untuk menerima stimulus

4. Saraf sensoris sebagai alat untuk meneruskan stimulus ke otak, yang kemudian sebagai alat untuk mengadakan respon.

Menurut Kotler dan Keller (2011), harga bukan hanya angka-angka dilabel harga, tetapi harga juga punya banyak bentuk dan melaksanakan banyak fungsi.Lebih lanjut lagi Kotler dan Keller menyatakan bahwa praktik penetapan harga telah mengalami perubahan besar dalam tahun-tahun terakhir.Banyak perusahaan melawan kecenderungan harga yang rendah dan berhasil mendorong konsumen membeli produk dan jasa yang lebih mahal dengan menggabungkan formulai produk unik yang melibatkan kampanye pemasaran. Perusahaan harus menetapkan harga pada saat pertama kali mereka mengembangkan produk baru, ketika perusahaan memperkenalkan produk regulernya ke saluran distribusi atau wilayah geografis baru, dan ketika perusahaan memasukkan penawaran pekerjaan kontrak baru. Perusahaan harus memutuskan di mana perusahaan akan memposisikan produknya berdasarkan kualitas dan harga. Oleh karena itu perusahaan harus mempertimbangkan banyak faktor dalam menentukan kebijakan penetapan harga.

Menurut Kotler dan Amstrong (2012), didalam variabel harga ada beberapa unsur kegiatan utama harga yang meliputi daftar harga, diskon, potongan harga, dan periode pembayaran. Indikator persepsi harga menurut Dwihapsari (2012) adalah :

a. Harga terjangkau Penetapan harga berdasarkan ukuran persepsi pelanggan.

b. Perbandingan harga dengan kompetitor. Penetapan harga sesuai dengan harga yang berlaku berdasarkan harga pesaing/komoetitor c. Kesesuaian harga dengan kualitas Penetapan harga disesuaikan dengan fasilitas dan produk yang ditawarkan.

Harga menurut(Kotler \& Keller 2013) adalah sejumlah nilai dari uang yang dikenakan atas produk dan jasa. Secara umum harga merupakan jumlah total nilai yang menjadi pertukaran oleh pelanggan untuk mendapatkan sebuah barang atau kepemilikan atas jasa. Menurut Lovelock \& Wirtz (2013) harga adalah pengeluaran uang, waktu dan tenaga yang ada karena pembelian barang dan memanfaatkan jasa. Kotler (2012) menyatakan bahwa harga juga merupakan salah satu elemen bauran pemasaran yang paling fleksibel.

Penerapan harga jual berasal dari harga pokok tersebut sedangkan harga pokok barang ditentukan oleh berapa besar biaya yang dikorbankan untuk memperoleh atau untuk membuat barang itu. Harga dapat diartikan sebagai jumlah uang atau satuan moneter dan atau aspek lain (non moneter) yang mengandung kegunaan tertentu yang diperlukan untuk mendapatkan suatu jasa ,Tjiptono, (2014). Pongoh, (2013) menyatakan harga mempunyai peranan penting dalam proses pengambilan keputusan yaitu peranan alokasi dari harga adalah membantu para pembeli untuk memutuskan cara memperoleh manfaat atau utilitas tertinggi yang diharapkan berdasarkan kekuatan daya belinya. Berdasarkan definisi-definisi diatas maka dapat disimpulkan bahwa hargaadalah sejumlah nilai yang ditukarkan oleh konsumen untuk memperoleh suatu manfaat atas barang atau jasa baik yang bisa dimiliki maupun digunakan fungsinya karena dimata konsumen harga merupakan atribut penting yang dievaluasi yang merangkap dengan nilai sosial non keuangan yang harus dikorbankan dan bagi perusahaan peran harga dapat membentuk sikap konsumen. 


\subsubsection{Definisi Citra Merek}

Merek merupakan hal yang sangat penting baik bagi konsuen maupun bagi produsen. Merek juga membantu meyakinkan konsumen, bahwa mereka akan mendapatkan kualitas yang konsisten setiap kali memilih merek tersebut saat melakukan pembelian. Bila tidak ada merek konsumen harus mengevaluasi semua produk setiap kali akan melakukan pembelian. Namun, saat konsumen telah memiliki kepercayaan terhadap sebuah merek akan memudahkan pada saat akan melakukan pembelian, Sulistyari, (2012).

Citra merek berpengaruh terhadap kepercayaan merek. Hal ini menjelaskan bahwa citra merek yang dipersepsikan oleh konsumen mempengaruhi timbulnya kepercayaan konsumen.Citra merek yang dipersepsikan oleh konsumen seperti adanya pandangan tentang kualitas, servis, perusahaan yang baik mampu membuat konsumen percaya. Cindy (2014). Konsumen yang memiliki kepercayaan pada merek tertentu lebih yakin dalam memutuskan pembelian, faktor internal tersebut sangat besar pengaruhnya terhadap keputusan pembelian ,Maslichah, (2013). Menurut Kotler dan Fox dalam Etta Mamang mendefinisikan citrasebagai jumlah dari gambaran-gambaran, kesan-kesan, dan keyakinan- keyakinan yang dimiliki seseorang terhadap suatu objek. Citra terhadap merek berhubungan dengan sikap yang berupa keyakinan dan preferensi terhadap suatu merek.

Mempertahankan citra merek sangat sulit dan tidak mudah, karena adanya perubahan-perubahan yang selalu terus maju sesuai dengan kebutuhan yang beragam jumlahnya bagi konsumen, hal ini akan berdampak pada ketertarikan konsumen mengenai produk dari merek tersebut, ketika konsumen akan melakukan keputusan pembelian, Maslichah, (2013). Pengaruh persepsi kualitas, citra merek dan dukungan layanan purna jual sangat mempengaruhi terhadap keputusan konsumen dalam membeli skuter matic merek Honda di Kota Semarang, ini menghasilkan penilaian bahwa citra merek berpengaruh positif dalam keputusan pembelian. Sri Wahyuni, (2013).

Menurut Sunyoto (2012), beberapa karakteristik suatu merek yang baik, yaitu:

1. Mudah dibaca, diucapkan dan diingat.

2. Singkat dan sederhana.

3. Mempunyai ciri khas tersendiri dan disenangi oleh konsumen seperti National, Toshiba.

4. Merek harus menggambarkan kualitas, prestise, produk dan sebagainya.

5. Bisa diadaptasi oleh produk-produk baru yang mungkin ditambahkan di lini produk.

6. Merek harus dapat didaftarkan dan mempunyai perlindungan hukum.

Indikator yang digunakan untuk pengukuran citra merek menurut Tambunan (2012) sebagai berikut :

1) Lambang atau logo merek mudah diingat Identitas yang mereprentasikan citra sebuah perusahaan dimata konsumen dan mudah dibedakan dengan perusahaan kompetitor atau pesaing.

2) Merek mudah dikenali Pelanggan dapat mengenali sebuah merek perusahaan berdasarkan ciri-cirinya sehingga pelanggan dapat langsung mengenali jasa atau produk yang dipasarkan ketika melihat merek perusahaan tersebut.

3) Merek yang terpecaya Merek dikenal akan kualitas jasa atau barang yang diberikan oleh suatu perusahaan.

\subsubsection{Definisi Kepuasan Pelanggan}

Banyak pakar yang mendefinisikan kepuasan konsumen berdasarkan persepektifnya masng-masing meskipun tidak terdapat satu definisi tunggal yang menjadi rujukan bersama mengenai 
kepuasan konsumen, namun pada intinya mereka menyatakan subtansi yang sama tentang kepuasan konsumen. Kepuasan konsumen merupakan perasaan senang atau kecewa seseorang yang timbul karena membandingkan pelayanan yang di persepsikan atau hasil terhadap ekspetasi mereka tindakan yang dilakukan konsumen.Perasaan senang atau kecewa tersebut terbentuk di dalam diri konsumen melalui kualitas produk, harga dan lokasi yang dirasakan Dalam Bailia, Soegoto \& Loindong, (2014).

Menurut Fandy Tjiptono (2014) kata "kepuasan atau satisfaction: berasal dari bahasa latin "satis" (artinya cukup banyak, memadai) dan "facio" (melakukan atau membuat) secara sederhana kepuasan dapat diartikan sebagai upaya pemenuhan sesuatu atau membuat sesuatu memadai. Menurut Howard dan sheth dalam Fandy Tjiptono (2014) mengungkapkan bahwa kepuasan pelanggan adalah situasi kognitif pembelian berkenaan dengan kesepadanan atau ketidak sepadanan antara hasil yang didapatkan dibandingkan dengan pengorbanan yang dilakukan. Sedangkan menurut Swan dalam Fandy tjiptono (2014) mendefinisikan kepuasan pelanggan sebagai evaluasi secara sadar atau atau penilaian kognitif menyangkut apakah kinerja produk relatif bagus atau jelek atau apakah produk bersangkutan cocok atau tidak cocok dengan tujuan atau pemakaiannya.

Kepuasan pelanggan dapat diukur dengan berbagai macam metode dan teknik.
Indikator dalam pengukuran kepuasan pelanggan menurut Kotler, (2012) :

1. Recommendation adalah merekomendasikan produk yang sudah dibeli pada konsumen lain.

2. Intention adalah niat untuk pembelian ulang.

3. Say good things adalah mengatakan hal yang baik setelah membeli.

Assauri (2012) menyatakan kepuasan pelanggan merupakan suatu indikator ke depan akan keberhasilan bisnis perusahaan, yang mengukur bagaimana baiknya tanggapan pelanggan terhadap masa depan bisnis perusahaan. Seluruh kegiatan yang dilakukan oleh sebuah perusahaan pada akhirnya bermuara pada nilai yang akan diberikan kepada pelanggan mengenai kepuasan yang dirasakan. Kepuasan adalah perasaan senang atau kecewa seseorang yang timbul karena membandingkan pelayanan yang dipersepsikan terhadap ekspektasi mereka. Jika pelayanan gagal memenuhi ekspektasi, pelanggan tidak puas. Jika pelayanan sesuai ekspektasi pelanggan akan puas. Kepuasan konsumen akan terpenuhi apabila proses pelayanan jasa kepada konsumen sesuai dengan apa yang dipersepsikan konsumen. Karena berbagai faktor, seperti subjektivitas yang dipersepsikan konsumen dan pemberi jasa, maka jasa sering disampaikan dengan cara yang berbeda dengan yang dipersepsikan konsumen (Lupiyoadi 2013) 


\subsection{Kerangka pikir}

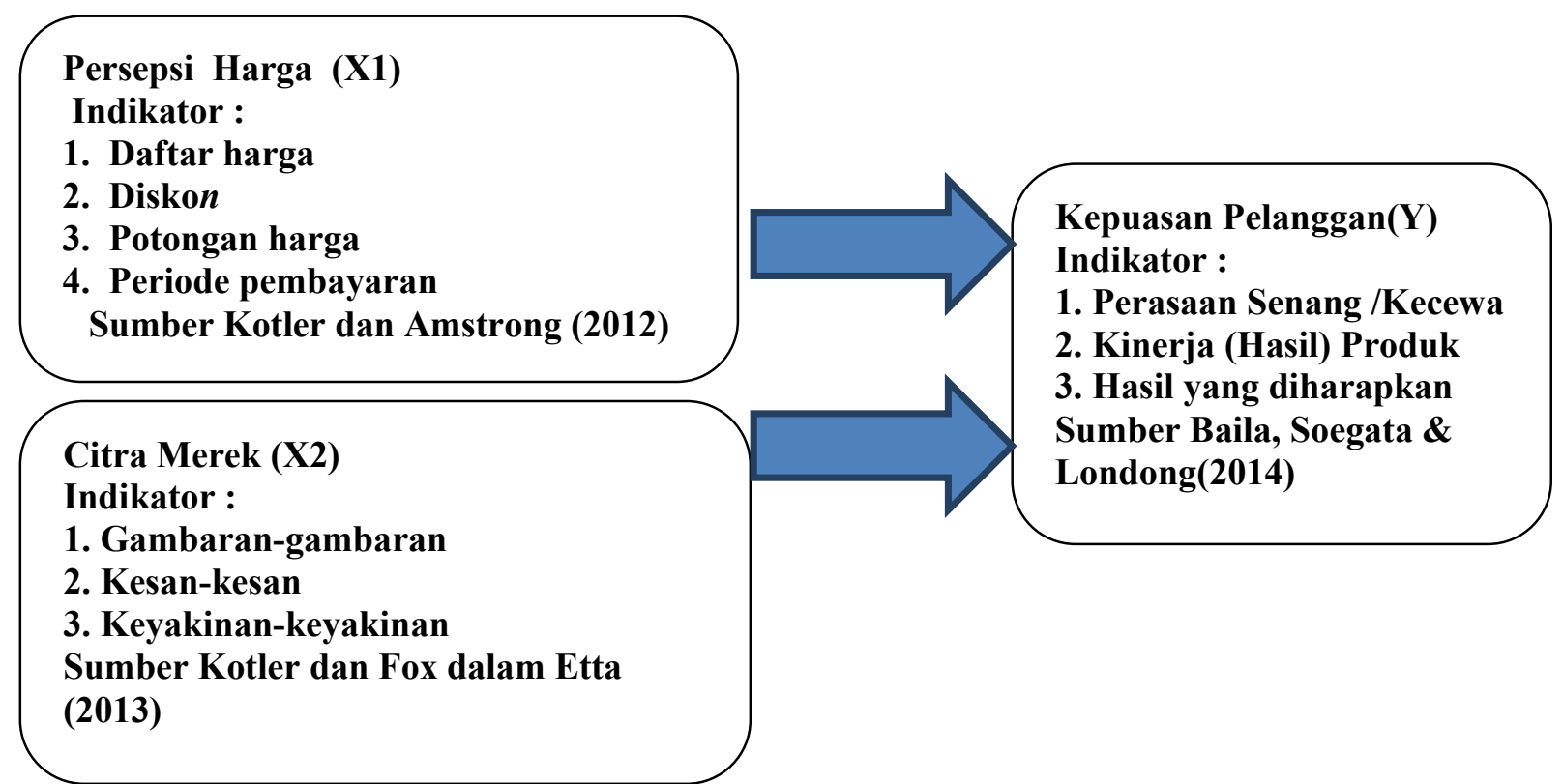

\subsection{Hipotesis}

Adapun hipotesis yang diajukan dalam penelitian ini adalah sebagai berikut :

1. Pengaruh Variabel Persepsi harga terhadap kepuasan konsumen pelanggan grab di kota Palembang.

Hol : Tidak terdapat pengaruh dan signifikan Persepsi harga terhadap kepuasan konsumen pelanggan grab di kota Palembang

Ha1 : Terdapat pengaruh dan signifikan Persepsi harga terhadap kepuasan konsumen pelanggan grab di kota Palembang

2. Pengaruh Variabel Citra merek terhadap kepuasan konsumen pelanggan grab di kota Palembang.

Ho2 : Tidak terdapat pengaruh dan signifikan Citra merek terhadap kepuasan konsumen pelanggan grab di kota Palembang

Ha2 : Terdapat pengaruh dan signifikan Citra merek terhadap kepuasan konsumen pelanggan grab di kota Palembang
3. Pengaruh Variabel Persepsi harga dan Citra merek terhadap kepuasan konsumen pelanggan grab di kota Palembang.

Ho3 : Tidak terdapat pengaruh dan signifikan Persepsi harga dan Citra merek terhadap kepuasan konsumen pelanggan grab di kota Palembang.

Ha3 : Terdapat pengaruh dan signifikan Persepsi harga dan Citra merek terhadap kepuasan konsumen pelanggan grab di kota Palembang.

\section{METODE PENELITIAN}

\subsection{Ruang Lingkup Penelitian}

Ruang lingkup penelitian ini terarah dan terukur serta tidak menyimpang dari permasalahan maka peneliti membatasi pada pengaruh gaya kepemimpinan terhadap kinerja pegawai.

\subsection{Rancangan penelitian}

Penelitian ini berjenis penelitian analisa kuantitatif yang membahas ada tidaknya pengaruh antara variabel bebas dan 
variabel terikat, dalam hal ini variabel bebas (x) adalah gaya kepemimpinan dan variabel tidak bebas (y) adalah kinerja pegawai.

\subsection{Tehnik pengumpulan data}

Metode pengumpulan data yang digunakan dalam penelitian ini adalah :

a. Kuesioner

Tehnik ini dilakukan dengan cara memberikan daftar pertanyaan kepada responden untuk di jawab, kemudian dari setiap pertanyaan ditentukan scornya untuk setiap jawaban dengan menggunakan skala.

b. wawancara

wawancara adalah kegiatan untuk mengumpulkan data pada objek penelitian dengan melakukan tanya jawab secara langsung dan pada objek responden.

c. Dekumentasi

Dekumentasi adalah sebuah
cara yang dilakukan untuk
menyediankan dokumen-dokumen
dengan menggunakan bukti yang akurat.

\subsection{Sumber data}

a. Data primer

Data primer yaitu tentang penyebab yang mempengaruhi gaya kepemimpinan terhadap kinerja pegawai. Data tersebut diperoleh dari hasil proses penilaian pegawai yang menjadi populasi kuesioner penelitian

b. Data sekunder

Data sekunder meliputi data mengenai sejarah instansi, struktur organisasi dan uraian tentang instansi, jumlah pegawai, buku buku ilmiah dan literatur lain yang berhubungan dengan masalah yang di teleti.

\subsection{Populasi dan sampel}

Populasi adalah wilayah generalisasi yang terdiri atas objek/subjek yang mempunyai kualitas dan karakteristik tertentu yang ditetapkan oleh peneliti untuk dipelajari dan kemudian ditarik kesimpulanya

Sampel adalah bagian dari jumlah dan karakteristik, misalnya karena keterbatasan dana, tenaga dan waktu, maka peneliti dapat mnguunakan sampel dari populasi itu. Apa yang dipelajari dari sampel populasi itu. sugiyono (2008 : 115) pada penelitian ini maka yang menjadi objek penelitian adalah pegawai basarnas yang bejumlah 65 pegawai yang terdiri dari : staf kaur umum berjumlah 12 pegawai, staf operasi berjumlah 40 orang dan staf potensi berjumlah 13 pegawai. Dalam penelitian ini menggunakan tehnik sensus yaitu mengambil seluruh populasi yang juga dijadikan sampel dalam hal ini seluruh pegawai basarnas sumatera selatan yang berjumlah 65 pegawai

\subsection{Teknik analisis}

\section{6 .1 Regresi linear sederhana}

Dalam penelitian ini dilakukan dari kuesioner yang telah teruji vadilitas dan reliabitasnya.metode yang digunakan dalam analisis data pada penelitian ini adalah analisis regresi ( regression analysis ). Analisis regresi digunakan untuk melihat seberapa besar pengaruh variabel bebas terhadap varibel tidak bebas.

Regresi sederhana dari penelitian ini adalah persamaan regresi yang menggamparkan hubungan antara variabel bebas ( indepence ) terhadap variabel terikat ( dependence ). Model umum persamaan regresi linier sederhana adalah :

$\mathrm{Y}=\mathrm{A}+\mathrm{bX}+\mathrm{e}$

Dimana: $Y$ adalah variabel kinerja pegawai

A : konstanta

$\mathrm{b}$ : koefisien regresi

$\mathrm{x}$ : standar error

Untuk menghitung nilai koefisien regresi dilakukan dengan metode kuadrat terkecil dengan bantuan paket program 
statistik SPSS versi 22. Setelah koefisien regesi diperoleh langkah selanjutnya adalah melakukan pengujian terhadap koefesien tersebut.

\subsubsection{Koefesien Determinasi}

Untuk mengetahui sebeapa besar kemampuan variabel indenpenden menjelaskan variabel dependen. Semakin besar nilai koefesien determinasi, maka semakin baik kemampuan variabel bebas semakin besar menjelaskan variabel terikat. Koefisien determinasi ( $\mathrm{R}^{2}$ ) pada intihnya seberapa jauh kemampuan dalam menerangkan variasi variabel dependen, nilai koefisien determinasi adalah antara nol dan satu. Nilai $\mathrm{R}^{2}=$ yang terkecil berarti kemampuan variabel variabel independen dalam menjelaskan variasi variabel dpenden amat tebatas.

\subsubsection{Uji T}

Menurut ghozali (2011:89) uji statistik $t$ pada dasarnya menunjukkan seberapa jauh pengaruh satu variabel independen secara induvidual dalam menerangkan variabel dependen.

berikut :

Hipotesis dirumuskan sebagai

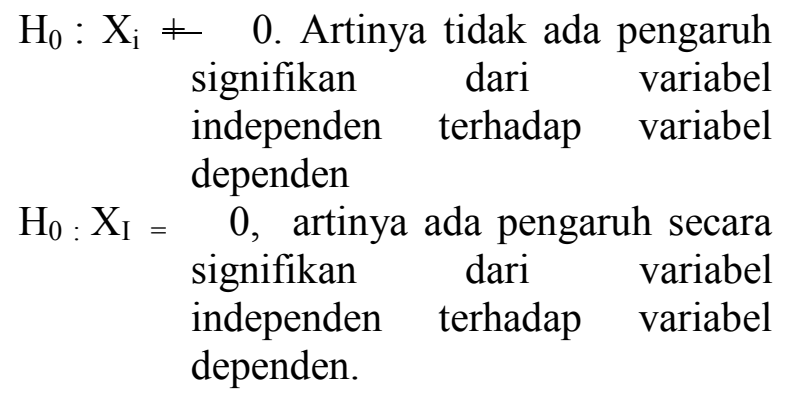

Penerimaan atau penolakan Hipotesis dilakukan dengan kriteria sebagai berikut :

1. jika nilai signifikan $\mathrm{t}$ statistik $>0,05$ atau $\mathrm{t}_{\text {tabel }}<$ hitung $<\mathrm{t}$-tabel' maka $\mathrm{H}_{0}$ diterimah. Hal ini berarti bahwa suatu variabel independen secara individual tidak mempunyai pengaruh terhadap variabel dependen.
2. Jika nilai signifikan $\mathrm{t}$ statistik $>0,05$ atau $\mathrm{t}_{\text {hitung }}>\mathrm{t}_{\text {tabel }}$ atau $\mathrm{t}_{\text {hitung }}<\mathrm{t}_{\text {tabel }}$ maka $\mathrm{H}_{0}$ ditolak, hal ini berarti bahwa suatu variabel independen secara induvidual mempengaruhi variabel dependen.

\section{HASIL PENELITIAN \\ 4.1 Hasil penelitian}

Persamaan regresi yang menggambarkan dan menjelaskan dua variabel bebas terhadap variabel terikat dapat digambarkan sebagai suatu garis lurus untuk melihat variabel karakteristik terhadap kinerja pegawai basarnas sumatera selatan maka peneliti mengguanakan model regresi berganda sebagai berikut :

$$
\mathbf{Y}=\mathbf{a}+\mathbf{b}_{1} \mathbf{x}_{1}+\mathbf{e}
$$

Dimana :

$\mathrm{Y}=$ Kepuasan Pelanggan

$\mathrm{a}=$ Konstanta

$b_{1}=$ Koefesien regresi

$\mathrm{X}_{1}=$ Persepsi Harga

$\mathrm{X}_{2}=$ Citra Merk

$\mathrm{e}=$ Standar eror

Perhitungan ini menggunakan regresi sederhana dengan mempergunakan SPSS. Dimana variabel $X_{1}$ adalah gaya kepemimpinan yang mempengaruhi variabel $\mathrm{Y}$ adalah kinerja pegawai.

\subsection{Analisis Data}

\subsubsection{Validasi Data}

Uji validasi adalah kecepatan dan kecermatan suatu alat ukur dalam melakukan fungsi ukurnya, suatu instrumen pengukur yang dapat dikatakan mempunyai validasi yang tinggi apabila instrumen tersebut menjalankan fungsi ukurnya atau memberikan hasil ukur yang sesuai dengan maksud dilakukan pengukuran tersebut ( suliyanto, 2006 : 149 ). Dalam analisis sistem, menurut suliyanto ( $2016: 149$ ) item yang mempunyai korelasi positif skor total serta korelasinya tinggi menunjukkan bahwa 
item tersebut mempunyai validasi tinggi pula. Syarat minimum untuk dianggap memenuhi syarat adalah $r$ hitung korelasi skor item terhadap skor total ( corrected item total corelation ) $=0,3$ jadi apabila $\mathrm{R}$ positif $>$ maka item valid, sedangkan $r$ negatif $<0,3$ maka item tidak valid.

\section{a. Validasi variabel Persepsi Harga}

Dari hasil pengujian validasi dengan menggunakan SPSS 19,0 ( hasil perhitungan dapat dilihat dalam lampiran ) diperoleh koefesien validasi dari setiap item dalam kuesioner, maka hasil terlihat dalam tabel berikut : untuk variabel persepsi harga $\left(\mathrm{X}_{1}\right)$, hasil dari validasi yang telah dilakukan menujukkan bahwa dari seluru item (5 butir) pertanyaan dalam kuesioner yang digunakan sebagai alat ukur. Secara terperinci nilai dari masing - masing item dapat ditunjukkan pada tabel berikut.

Tabel 4.1

Hasil uji Validasi Persepsi Harga $\left(\mathrm{X}_{1}\right)$

\begin{tabular}{|c|c|c|}
\hline Butir pertanyaan & $\begin{array}{c}\text { Corrected item total } \\
\text { correted }\end{array}$ & Status \\
\hline Pertanyaan 1 & 0,749 & Valid \\
\hline Pertanyaan 2 & 0,974 & Valid \\
\hline Pertanyaan 3 & 0,951 & Valid \\
\hline Pertanyaan 4 & 0,693 & Valid \\
\hline Pertanyaan 5 & 0,895 & Valid \\
\hline Pertanyaan 6 & 0,867 & Valid \\
\hline
\end{tabular}

Tabel 4.2

Item total statistik

\begin{tabular}{|c|c|c|c|c|}
\hline $\begin{array}{c}\text { Butir } \\
\text { pertanyaan }\end{array}$ & $\begin{array}{c}\text { Scale mean if } \\
\text { item deleted }\end{array}$ & $\begin{array}{c}\text { Scale variance } \\
\text { if item } \\
\text { delected }\end{array}$ & $\begin{array}{c}\text { Corrected } \\
\text { item total } \\
\text { coreelation }\end{array}$ & $\begin{array}{c}\text { Cronbach's } \\
\text { Alpha if item } \\
\text { delected }\end{array}$ \\
\hline Pertanyaan 1 & 66.0000 & 2965.000 & 0.749 & 0.950 \\
\hline Pertanyaan 2 & 66.0000 & 2234.500 & 0.974 & 0.916 \\
\hline Pertanyaan 3 & 66.0000 & 2261.500 & 0.951 & 0.919 \\
\hline Pertanyaan 4 & 66.0000 & 2461.000 & 0.693 & 0.957 \\
\hline Pertanyaan 5 & 66.0000 & 2512.500 & 0.895 & 0.928 \\
\hline Pertanyaan 6 & 66.0000 & 2571.500 & 0.867 & 0.932 \\
\hline
\end{tabular}

Hasil olah data SPSS 19

\section{b. Validasi variabel Citra Merek}

Untuk variabel citra merk $\left(\mathrm{X}_{2}\right)$, hasil dari uji validasi yang telah dilakukan menunjukkan bahwa seluru item 6 butir pertanyaan dalam kuesioner digunakan sebagai alat ukur variabel citra merk $\left(\mathrm{X}_{2}\right)$ Ternyata semua item pertanyaan dinyatakan valid. Secara terperinci bila dari masing masing item dapat dilihat dalam tabel berikut ini :

Tabel 4.3

Hasil uji validasi Citra Merk $\left(X_{2}\right)$

\begin{tabular}{|c|c|c|}
\hline Butir pertanyaan & $\begin{array}{c}\text { Corrected item total } \\
\text { correted }\end{array}$ & Status \\
\hline Pertanyaan 1 & 0,991 & Valid \\
\hline Pertanyaan 2 & 0,995 & Valid \\
\hline
\end{tabular}




\begin{tabular}{|c|c|c|}
\hline Pertanyaan 3 & 0,984 & Valid \\
\hline Pertanyaan 4 & 0,981 & Valid \\
\hline Pertanyaan 5 & 0,865 & Valid \\
\hline Pertanyaan 6 & 0,899 & Valid \\
\hline
\end{tabular}

\section{c. Validasi variabel Kepuasan Pelanggan (Y)}

Untuk variabel kepuasan pelanggan (Y), hasil dari uji validasi yang telah dilakukan menunjukkan bahwa seluru item 6 butir pertanyaan dalam kuesioner digunakan sebagai alat ukur variabel (Y) Ternyata semua item pertanyaan dinyatakan valid. Secara terperinci bila dari masing - masing item dapat dilihat dalam tabel berikut ini :

Tabel 4.4

Item total statistik

\begin{tabular}{|c|c|c|c|c|}
\hline $\begin{array}{c}\text { Butir } \\
\text { pertanyaan }\end{array}$ & $\begin{array}{c}\text { Scale mean if } \\
\text { item deleted }\end{array}$ & $\begin{array}{c}\text { Scale variance } \\
\text { if item } \\
\text { delected }\end{array}$ & $\begin{array}{c}\text { Corrected } \\
\text { item total } \\
\text { coreelation }\end{array}$ & $\begin{array}{c}\text { Cronbach's } \\
\text { Alpha if item } \\
\text { delected }\end{array}$ \\
\hline Pertanyaan 1 & 66.0000 & 4573.500 & 0.996 & 0.977 \\
\hline Pertanyaan 2 & 66.0000 & 4901.000 & 0.995 & 0.978 \\
\hline Pertanyaan 3 & 66.0000 & 4636.000 & 0.984 & 0.978 \\
\hline Pertanyaan 4 & 66.0000 & 5004.500 & 0.981 & 0.980 \\
\hline Pertanyaan 5 & 66.0000 & 5015.500 & 0.865 & 0.989 \\
\hline Pertanyaan 6 & 66.0000 & 4702.500 & 0.899 & 0.987 \\
\hline
\end{tabular}

Hasil olah data SPSS 19

Untuk variabel kepuasan pelangganm (Y), hasil dari uji validasi yang telah dilakukan menunjukkan bahwa seluru item 6 butir pertanyaan dalam kuesioner digunakan sebagai alat ukur variabel kinerja (Y) Ternyata semua item pertanyaan dinyatakan valid. Secara terperinci bila dari masing - masing item dapat dilihat dalam tabel berikut ini :

Tabel 4.3

Hasil uji validasi kepuasan pelanggan (Y)

\begin{tabular}{|c|c|c|}
\hline Butir pertanyaan & $\begin{array}{c}\text { Corrected item total } \\
\text { correted }\end{array}$ & Status \\
\hline Pertanyaan 1 & 0,996 & Valid \\
\hline Pertanyaan 2 & 0,995 & Valid \\
\hline Pertanyaan 3 & 0,984 & Valid \\
\hline Pertanyaan 4 & 0,981 & Valid \\
\hline Pertanyaan 5 & 0,865 & Valid \\
\hline Pertanyaan 6 & 0,899 & Valid \\
\hline
\end{tabular}

Tabel 4.4

Item total statistik

\begin{tabular}{|c|c|c|c|c|}
\hline $\begin{array}{c}\text { Butir } \\
\text { pertanyaan }\end{array}$ & $\begin{array}{c}\text { Scale mean if } \\
\text { item deleted }\end{array}$ & $\begin{array}{c}\text { Scale variance } \\
\text { if item } \\
\text { delected }\end{array}$ & $\begin{array}{c}\text { Corrected } \\
\text { item total } \\
\text { coreelation }\end{array}$ & $\begin{array}{c}\text { Cronbach's } \\
\text { Alpha if item } \\
\text { delected }\end{array}$ \\
\hline Pertanyaan 1 & 66.0000 & 4573.500 & 0.996 & 0.977 \\
\hline Pertanyaan 2 & 66.0000 & 4901.000 & 0.995 & 0.978 \\
\hline Pertanyaan 3 & 66.0000 & 4636.000 & 0.984 & 0.978 \\
\hline Pertanyaan 4 & 66.0000 & 5004.500 & 0.981 & 0.980 \\
\hline
\end{tabular}




\begin{tabular}{|c|c|c|c|c|}
\hline Pertanyaan 5 & 66.0000 & 5015.500 & 0.865 & 0.989 \\
\hline Pertanyaan 6 & 66.0000 & 4702.500 & 0.899 & 0.987 \\
\hline
\end{tabular}

Hasil olah data SPSS 19

\subsubsection{Uji realibilitas}

Reabilitas merupakan tingkat keandalan suatu instrumen penelitian, instrumen yang reliabel adalah instrumen yang apabila digunakan berulang kali untuk mengukur objek yang disamakan menghasilkan data yang sama (Sugiyono, 2008 :10). Uji realibilitas akan dapat menunjukkan konsistensi dari jawaban jawaban responden yang terdapat pada kuesioner. Uji ini dilakukan setelah uji vadilitas dan yang diuji merupakan pertanyaan yang suah valid, pengujian dilakukan dengan menggunakan program SPSS 19 for windows dengan kriteria sebagai berikut :

a. Jika nilai cronbach's Alpha $>0,60$ Maka variabel atau konstruk tersebut dinyatakan reliabel.

b. Jika nilai cronbach's Alpha $<0,60$ maka variabel atau konstruk tersebut dinyatakan tidak reliabel

Hasil uji reliabilitas secara terperinci dapat dilihat pada tabel berikut ini :

Tabel 4.5

Hasil uji realibilitas

\begin{tabular}{|l|c|c|}
\hline \multicolumn{1}{|c|}{ Variabel } & $\begin{array}{c}\text { Alpha } \\
\text { cronbach } \\
\text { (a) }\end{array}$ & Status \\
\hline $\begin{array}{l}\text { Persepsi } \\
\text { Harga }\end{array}$ & 0.974 & Reliabel \\
\hline Citra Merk & 0.995 & Reliabel \\
\hline $\begin{array}{l}\text { Kepuasan } \\
\text { Pelanggan }\end{array}$ & 0,996 & Reliabel \\
\hline
\end{tabular}

a. Realibilitas Persepsi Harga

Tabel 4.6

Realibility statistic - Persepsi Harga

\begin{tabular}{|c|c|}
\hline Cronbach's Alpha & N of items \\
\hline 0.974 & 6 \\
\hline
\end{tabular}

b. Realibilitas Citra Merk

Tabel 4.7

Realibility statistic - Citra Merek

\begin{tabular}{|c|c|}
\hline Cronbach's Alpha & N of items \\
\hline 0.995 & 6 \\
\hline
\end{tabular}

c. Realibilitas Kepuasan Pelanggan

Tabel 4.8

Realibility statistic - Kepuasan Pelanggan

\begin{tabular}{|c|c|}
\hline Cronbach's Alpha & N of items \\
\hline 0.996 & 6 \\
\hline
\end{tabular}

4.3 Analisi deskriftip Statistik

4.3.1 Koefesien Determinasi $\left(R^{2}\right)$

Digunakan untuk melihat seberapa besar pengaruh variabel bebas terhadap variabel terikat. Dengan kata lain, koefesien determinasi digunakan untuk mengukur besarnya pengaruh variabel bebas yang diteliti yaitu Persepsi Harga $\left(\mathrm{X}_{1}\right)$, Citra Merk $\left(\mathrm{X}_{2}\right)$ Terhadap Kepuasan Pelanggan (Y). Dalam output SPSS, koefesien determinasi terletak pada tabel model summary dan tertulis $\mathrm{R}$ square. Besarnya $\mathrm{R}$ Square semakin kecil atau mendekati angka 0 (nol) maka hubungan antara variabel bebas (X) Dengan variabel terikat (Y) semakin lemah. Sebaliknya apabila R square semakin besar atau mendekati angka 1 (satu) maka hubungan antara variabel semakin kuat.

Tabel 4.8

Model summary

\begin{tabular}{|c|c|c|c|c|}
\hline $\begin{array}{l}\text { Mod } \\
\text { el }\end{array}$ & $\mathrm{R}$ & $\begin{array}{l}\text { R } \\
\text { Squa } \\
\text { re }\end{array}$ & $\begin{array}{l}\text { Adjust } \\
\text { ed R } \\
\text { square }\end{array}$ & $\begin{array}{l}\text { Std. } \\
\text { Error } \\
\text { of the } \\
\text { estima } \\
\text { te }\end{array}$ \\
\hline 1 & $\begin{array}{l}0.14 \\
8^{\mathrm{a}}\end{array}$ & 0.022 & 0.007 & $\begin{array}{l}3.0409 \\
1\end{array}$ \\
\hline
\end{tabular}

Predictors : ( constant ) X1 
a.R dalam analisis regresi berganda menunjukkan korelasi yaitu korelasi antara dua variabel independent. Angka $\mathrm{R}$ didapat 0,148 artinya morelasi variabel dengan kinerja pegawai 0,148 .

b.R Square $\left(\mathrm{R}^{2}\right)$ atau kuadrat dari $\mathrm{R}$ yaitu menunjukkan nilai koefesien determinasi. Angka ini akan diubah kebentuk persentase sumbangan pengaruh variabel indefendent terhadap variabel dependent. Nilai $\mathrm{R}^{2}$ sebesar $0,022 \%$ artinya persentase gaya kepemimpinan terhadap kinerja pegawai sebesar $\quad 0,022 \%$ sedangkan sisanya dipengaruhi variabel lain yang tidak dimasukkan dalam model ini.

c.Adjusted R square adalah $\mathrm{R}$ square yang telah disesuaikan nilai sebesar 0,007 menunjukkan sumbangan variabel independent terhadap variabel dependent.

d.Standar error of estimated ( standar deviasi ) adalah ukuran kesalahan prediksi , nilai sebesar 3,04091.

\subsubsection{Uji - T ( secara persial )}

Uji t atau uji koefisien regresi secara parsial digunakan untuk mengetahui apakah secara parsial variabel independent berpengaruh secara signipikan atau tidak terhadap variabel dependent. Dalam hal ini mengetahui apakah secara parsial kinerja pegawai basarnas sumatera selatan. Pengujian menggunakan tingkat signifikansi 0.05 .

\begin{tabular}{|c|c|c|c|c|}
\hline Model & $\begin{array}{c}\text { Unstandardized } \\
\text { coeffecient }\end{array}$ & $\begin{array}{c}\text { Standardized } \\
\text { coefecient }\end{array}$ & $\mathbf{t}$ & sig \\
\hline 1 & 25,919 & & 10,934 & 0,000 \\
(Constant) & $-0,104$ & $-0,148$ & $-1,195$ & 0,236 \\
\hline
\end{tabular}

Pengujian variabel $\left(b_{1}\right)$ dengan hipotesis :

$\mathrm{H}_{0}$ : koefesien regresi (persepsi harga) tidak terlalu berpengaruh secara parsial terhadap kepuasan pelanggan

$\mathrm{H}_{1}$ : koefesien regresi (persepsi harga) berpengaruh secara parsial terhadap kepuasan pelanggan. Berdasarkan hasil dari output $t$ hitung diperoleh sebesar -1.195 untuk mencari $t_{\text {tabel }}$ pada signifikan 0,05 dengan derajat kebebasan $\mathrm{df}=\mathrm{n}-\mathrm{k}-1$ atau $66-1-1=64$ maka diperoleh nilai untuk $t$ tabel 1.645 .

Jika $t_{\text {hitung }}, \mathrm{t}_{\text {tabel }}(\mathrm{N} 1.645)$, Maka $\mathrm{H}_{\mathrm{o}}$ diterimah artinya bahwa gaya kepemimpinan secara parsial berpengaruh terhadap kinerja.

\section{KESIMPULAN DAN SARAN}

\subsection{Kesimpulan}

Bedasarkan hasil analisis dan pembahasan pada bab sebelumnya, maka dapat disimpulkan adanya pengaruh persepsi harga dan citra merek terhadap kepuasan pelanggan pada jasa transportasi ojek online (Grab) di kota Palembang digambarkan dari hasil pengelolaan data, Dari hasil uji koefisiensi determinasi (R2) pengaruh yang diberikan dari variabel persepsi harga dan citra merek secara bersama-sama terhadap kepuasan pelanggan sebesar 80,1\% , sedangkan sisanya sebesar $19,9 \%$ kepuasan pelanggan dipengaruhi oleh variabel lain tidak menjadi fokus dalam penelitian ini. Yang berarti bahwa hipotesis dalam penelitian ini menerima $\mathrm{H} 1$ dan menolak Ho.

\subsection{Saran}

Bedasarkan kesimpulan yang telah dituliskan diatas maka saran yang dapat diberikan dalam penelitian ini yaitu :

1. Bagi perusahaan agar lebih
memperhatikan Persepsi harga yang 
timbul ditengah masyarakat agar hal ini tidak menghasilkan persepsi yang buruk sehingga akan berdampak dalam kepuasan pelanggan grab di kota Palembang. Selanjutnya perusahaan diharapkan selektif lagi dalam memilih driver agar citra-citra buruk tidak tumbuh dalam pemikiran pelanggan, tentu saja hal ini dapat berdampak buruk bagi perusahaan.

2. Bagi penelitian selanjutnya, Hasil uji R2 menunjukkan bahwa ada variabelvariabel lain yang ternyata juga berdampak terhadap kepuasan pelanggan, terbukti ada nilai 19,9\% hal yang mempengaruhi kepuasan pelanggan diluar variabel dalam penelitian ini. Untuk mendapatkan kesimpulan yang lebih menyeluruh dan mendalam, kiranya penelitian di masa yang akan dating dapat mempertimbangkan faktor-faktor lain seperti pelayanan, kondisi kendaraan, komunikasi driver, ketepatan waktu, dan serta sebagainya.

\section{Daftar Pustaka}

Amstrong. Kotler. (2015). Marketing an Introducing Prentice Hall twelfth edition.England: Pearson Education, Inc.

Arikunto. 2006. Prosedur Penelitian Suatu Pendekatan Praktek. Jakarta : PT. Rineka Cipta.

$\begin{array}{ccc}\text { Assauri,S . (2012). } & \text { Strategi } & \text { Marketing } \\ \text { Sustaining } & \text { Lifetime } & \text { Customer } \\ \text { Value.Raja } & \text { Garfindo } & \\ \text { Persada. } & & \end{array}$

Lupiyoadi, R. (2013). Manajemen Pemasaran Jasa Berbasis Kompetensi Edisi Pertama. Jakarta (ID). Salemba Empat.
Bachtiar. (2011). Analisa Faktor- Faktor yang Mempengaruhi Kepuasan Mahasiswa dalam Memilih Politeknik Sawunggalih Aji Purworejo. Dinamika Sosial Ekonomi Vol 7 No. 1.

Dwihapsari, Bunga Caecaria and Santosa, Suryono Budi (2012) Analisis pengaruh kualitas pelayanan dan persepsi harga terhadap kepuasan konsumen dalam menggunakan jasa pada Oryza Tour. Undergraduate thesis, Fakultas Ekonomika dan Bisnis. Universitas Diponegoro Semarang.

Etta Mamang Sangadji dan Sopiah, Perilaku Konsumen, ANDI, Yogyakarta, (2013).

FandyTjiptono." PemasaranJasa”. (2016). Malang: Bayumedia.

Fransisca,CindyTingkir. (2014). "Pengaruh Identitas Merek Terhadap Loyalitas Merek melalui Citra Merek Dan Kepercayaan Merek Toyota”. Jurnal Manajemen Pemasaran No. 2, Oktober 2014 Doi: 10.9744 / Pemasaran. 8.2.62-69 ISSN 1907 $235 x$.

Ghozali, Imam. 2011. Aplikasi Analisis Multivariat Dengan Program SPSS. Semarang Badan Penerbit Universitas Diponegoro

Https://idtesis.com/teorilengkaptentangcitra $\underline{\text { merekmenurutparaahlidancontohtesis }}$ citrameek

Janah, Maslichah Raichatul. (2013). Hubungan Antara Citra Merek Mobil Suzuki Dengan

Keputusan Pembelian Pada Konsumen Di Dealer Sumber Baru Mobil Purwokerto. Program Studi 
Psikologi Fakultas Ilmu Kesehatan. Universitas Sahid Surakarta.

Juliati, Sri Dalam Tribun News edisi 1 September 2019

Kotler, P., \& Keller, K. (2012).Manajemen Pemasaran. Jakarta: PT. INDEKS.

Kotler. P. 2012, ManajemenPemasaran :Analisis, Perencanaan, Implementasi dan Pengendalian, Edisi ke-2, Penerbit Erlangga, Jakarta

Kotlerdan Amstrong (2012) "Marketing Mix. Bauran Pemasaran. Digilib. unpas.ac.id, Kajian Pustaka.

Kotler, Philip dan Kevin L. Keller, 2013, Manajemen Pemasaran Jasa Edisi Satu, Jakarta: Salemba

Kotler. Philip dan Keller. Kevine Lane. 2016. Marketing Management 15th Edition. United State of America: Pearson Education Limited.

LovelockdanWirtz. (2013). Service Marketing. 7th edition. Global Edition. Person Pretince Hall.

Pongoh, M,. E. (2013) Kualitas Pelayanan, Kualitas Produk dan Harga Pengaruhnya Terhad

Loyalitas Pelanggan Kartu As Telkomsel Di Kota Manado. Jurnal EMBA. Vol. 1

Ramadhani, A. 2011.Pengaruh Faktor Psikologis Terhadap keputusan pembelian Sepeda Motor MerekYamaha.Jurnal Ekonomi Manajemen, Fakultas EkonomiUniversitas Gunadarma.

Sri Wahyuni, 2013. Analisis Pengaruh Kualitas Produk, Citra Merek dan Dukungan Layanan Purna Jual Terhadap Keputusan Konsumen dalam membeli Skuter Matic Merek Honda di Kota Semarang.
Jurnal Pengembangan Humaniora Vo.13 No.2, Agustus 2013 Diakses tanggal 15 Desember 2015.

Sugiyono (2011). Metode penelitian kuntitatif kualitatif dan R\&D. Alfabeta

Sugiyono. (2014). Metode Penelitian Pendidikan Pendekatan Kuantitatif, Kualitatif, dan R\&D. Bandung: Alfabeta.

Sunyoto, Danang. 2012. Konsep dasar riset pemasaran dan perilaku konsumen. Penerbit ,CAPS. Yogyakarta.

Tambunan, Krystia and Widiyanto, Ibnu (2012)Analisa pengaruh citra merek, persepsi kualitas, dan harga terhadap keputusan pembelian bandeng presto (Studi kasus pada konsumen di Bandeng Presto Semarang). Undergraduate thesis, Fakultas Ekonomi dan Bisnis. Universitas Diponegoro Semarang.

Tjiptono, F. Dan G. Candra. 2014. PemasaranJasa. Yogyakarta : ANDI. 